* Graduada em Direito pela Faculdade de Direito de Bauru. Mestre em Direito pela Instituição Toledo de Ensino. Professora efetiva da Universidade Estadual de Londrina, em regime de dedicação exclusiva. E-mail: nememirelle@gmail.com

**Graduada em Direito pela Universidade Estadual de Londrina. Mestre em Direito pela Universidade de Marília. Doutora em Estudos da Linguagem pela Universidade Estadual de Londrina. Professora efetiva do Departamento de Direito Público da Universidade Estadual de Londrina. Coordenadora do Colegiado do curso de Direito da Universidade Estadual de Londrina.E-mail: silviatacla@, uel.br

***Graduada em Direito pela UniversidadeEstadualdeLondrina. Pós-graduanda em Direito do Estado pela Universidade Estadual de Londrina. Aluna especial na disciplina "Dimensões estruturais e econômicas do Direito Internacional" do Mestrado em Direito Negocial da Universidade Estadual de Londrina.E-mail: sofiasanches26@hotmail.com

\section{Ativismo Judicial: Uma Análise do Papel do Poder Judiciário no CENÁrio Brasileiro ContemporÂNEo}

\author{
JUDICIAL ACTIVISM: AN ANALYSIS OF THE JUDICIARY`S ROLE \\ IN THE BRAZILIAN CONTEMPORARY SCENARIO
}

\section{Mirelle Neme Buzalaf* \\ Silvia Regina Tacla** \\ Sofia Sanches Sacoman***}

Como citar: BUZALAF, Mirelle Neme; TACLA, Silvia Regina; SACOMAN, Sofia Sanches. Ativismo judicial: uma análise do papel do Poder Judiciário no cenário brasileiro contemporâneo. Revista do Direito Público, Londrina, v. 16, n. 2, p. 10-25, ago. 2021. DOI: $10.5433 / 24157-108104-1.2021 v 16 n 2 p .10$. ISSN: $1980-511 X$

Resumo: Com a finalidade de discorrer sobre os efeitos trazidos pelo ativismo judicial ao Estado Democrático de Direito, este trabalho busca evidenciar a lesão ao princípio da separação dos poderes diante das recentes decisões do Pretório Excelso. Para tanto, a pesquisa foi baseada principalmente em livros e artigos referentes à área de Direito Constitucional, bem como em jurisprudências do Supremo Tribunal Federal. Nessa toada, o estudo começa com breves considerações sobre a importância da separação dos poderes para o constitucionalismo contemporâneo para, logo após, demonstrar a violação a esse princípio por meio do ativismo judicial empregado pela Corte Suprema, por exemplo, nos casos da mutação constitucional do artigo 52, inciso $\mathrm{X}$ da Constituição Federal, da criminalização da homofobia e da instauração do "inquérito das fake news". Por fim, alcança-se o entendimento de que a falta de uma limitação à prática ativista coloca em perigo a harmonia e a independência entre os Poderes e, em última análise, a própria estrutura democrática.

Palavras-chave: Ativismo judicial; Poder Judiciário; Separação dos poderes; Brasil.

Abstract: In order to discuss the effects brought by judicial activism to the democratic rule of law, this paper seeks to highlight the injury to the principle of separation of powers in the 
face of recent decisions of the Supreme Court. To this end, the research was based primarily on books and articles related to the area of Constitutional Law, as well as case law of the Supreme Court. In this vein, the study begins with brief considerations on the importance of separation of powers for contemporary constitutionalism to, soon after, demonstrate the violation of this principle through judicial activism employed by the Supreme Court, for example, in cases of constitutional mutation of Article 52, item $\mathrm{X}$ of the Federal Constitution, the criminalization of homophobia and the establishment of the "inquiry of fake news". Finally, it reaches the understanding that the lack of a limitation on the activist practice endangers the harmony and independence between Powers and, ultimately, the democratic structure itself.

Keywords: Judicial activism; Judiciary; Separation of powers; Brazil. 


\section{INTRODUÇÃO}

É de constatação geral o fato de que o Poder Judiciário exsurge na contemporaneidade como um poder de relevância destacada, sobretudo no que atine ao seu órgão máximo, o Supremo Tribunal Federal. Trata-se de uma conjuntura propiciada pelo aparato organizacional pátrio, que, fundado sobre as bases do constitucionalismo, destaca a função do Pretório Excelso de guarda da Lei Maior. Todavia, oportuno observar que um dos principais pontos defendidos pelos movimentos constitucionalistas para que seja assegurada a supremacia constitucional é justamente a separação de poderes, a qual é colocada em constante risco diante do ativismo judicial no Brasil.

Com referido apontamento em mente, o intuito do presente trabalho é analisar o cenário de atuação daquela Corte à luz do princípio da separação dos poderes, de maneira a possibilitar uma conclusão sobre os efeitos benéficos ou prejudiciais do ativismo judicial no ordenamento brasileiro. Para tanto, buscar-se-á demonstrar que a ampliação das atribuições do Judiciário contidas na Constituição Federal de 1988 culminam na judicialização de questões que antes eram deixadas fora do âmbito decisório do Judiciário, mas que esse fato, por si só, não implica em uma atuação que extrapole os contornos de independência e harmonia com os demais poderes.

Através da análise da estrutura e atribuições do Poder Judiciário constantes da Constituição, das decisões proferidas pelo Supremo Tribunal Federal em sede de controle de constitucionalidade e da diferenciação entre judicialização e ativismo, procurar-se-á traçar os limites entre atuação que visa a efetivação de direitos, por vezes negligenciada pelos demais poderes e a atuação criativa no sentido de desconsiderar as funções típicas dos outros poderes.

Desse modo, será utilizado o método dedutivo através da pesquisa majoritariamente bibliográfica de artigos e livros, com enfoque aos afetos à área de Direito Constitucional, e o indutivo na análise dos argumentos expostos em decisões do Supremo Tribunal Federal que permitam averiguar sua compatibilidade com a Constituição de 1988.

Nessa linha, o primeiro tópico do estudo destinar-se-á à explanação acerca da teoria da separação dos poderes e da sua consonância com os elementos substanciais do Estado Democrático de Direito. Em um segundo momento, discorrer-se-á sobre as funções atribuídas ao Poder Judiciário para que, logo na sequência, passe-se a conceituar o ativismo judicial e a diferenciá-lo do fenômeno da judicialização.

Por derradeiro, serão trazidas decisões recentemente tomadas pelo órgão de cúpula do Judiciário e que se mostrem aptas a demonstrar as reais consequências da prática ativista, o que a rigor inclui a intromissão em outra esfera de competência e, portanto, a ameaça a valores democráticos.

Em suma, será perquirido em que medida é possível a convivência entre uma atuação criativa do judiciário, que não se confunde com o fenômeno da judicialização, tanto na interpretação de dispositivos constitucionais quanto ante a omissão legislativa, e o princípio da separação dos poderes demonstrando-se que, por ter o monopólio da última palavra, a atuação judicial deve estar balizada pela autocontenção e pelo respeito à tripartição do poder. 


\section{A SEPARAÇÃO DE PODERES NO ESTADO BRASILEIRO}

A ideia da separação de poderes perpassou pensadores como Aristóteles, Marsílio de Pádua e John Locke, mas foi somente em 1748, com Montesquieu, que a teoria passou a ser entendida como um sistema que comporta os poderes Executivo, Legislativo e Judiciário, independentes e harmônicos entre si. Sua finalidade está relacionada à limitação do poder estatal, intento este que acabou por ser abarcado pelas constituições modernas, de maneira a acarretar a visão de impossibilidade de democracia sem separação de poderes (DALLARI, 2016, p. 216).

Nesse sentido, esclarece Montesquieu (1996 apud FACHIN, 2015, p. 204):

Quando, na mesma pessoa ou no mesmo corpo de magistratura, o poder legislativo está reunido ao poder executivo, não existe liberdade; porque se pode temer que o mesmo monarca ou o mesmo senado crie leis tirânicas para executá-las tiranicamente. Tampouco existe liberdade se o poder de julgar não for separado do poder legislativo e do executivo. Se estivesse unido ao poder legislativo, o poder sobre a vida e a liberdade dos cidadãos seria arbitrário, pois o juiz seria legislador. Se estivesse unido ao poder executivo, o juiz poderia ter a força de um opressor.

Referida teoria foi acolhida pelo parágrafo $5^{0}$ da Declaração de Direitos da Virgínia (1776) - o qual determinou que o Judiciário fosse separado e diferenciado dos poderes Executivo e Legislativo -, bem como passou a fazer parte da própria noção de constitucionalismo, visto que a Declaração dos Direitos do Homem e do Cidadão (1789) afirmou, em seu artigo XVI, que "toda sociedade na qual a garantia dos direitos não está assegurada, nem a separação dos poderes determinada, não tem Constituição.” (DALLARI, 2016, p. 216).

Nesse ponto, oportuno observar que o termo "constitucionalismo" está vinculado ao entendimento que prega a restrição do poder e a supremacia da lei (Estado de direito). Somado à ideia de "democracia", que se resume na defesa da soberania popular e do governo da maioria, origina-se o Estado Democrático de Direito, trazido pelo artigo $1^{0}$ da Constituição Federal de 1988 (BARROSO, 2015, p. 112-113).

No Brasil, a concepção da separação de poderes surgiu com a Constituição de 1824 e se mantém até hoje na Constituição Federal de 1988, a qual delineia, em seu artigo $2^{0}$, que os poderes da União são independentes e harmônicos entre si e subdividem-se em Legislativo, Executivo e Judiciário. Tal conjuntura foi elevada à condição de cláusula pétrea por meio do artigo $60, \S 4^{0}$, inciso III da Lei Maior, de modo a estabelecer um limite material à modificação constitucional (BRASIL, 1988).

Assim, é possível afirmar que a tese da separação de poderes mostra-se em conformidade com a forma federativa de Estado, adotada pela Constituição Federal em seu artigo $1^{\circ}$ (BRASIL, 1988). O Estado Federal, oriundo da Constituição dos Estados Unidos da América (1787), é aquele no qual existem dois centros de poder - o central e o federado -, o que permite unir a observância à 
diversidade de cada ente político à unidade indispensável ao respeito da soberania e da integridade nacionais (BARROSO, 2015, p. 207). A União representa o ente federativo central, titular do poder federal, enquanto o poder federado é realizado pelos Municípios e Estados-membros; somados poder federal e poder federado, tem-se o poder nacional (BARROSO, 2015, p. 207).

Como explicita Dallari (2016, p. 253), os constituintes norte-americanos, ao estabelecerem o Estado Federal, foram fortemente influenciados pelo princípio da separação dos poderes, proposto por Montesquieu. Adotou-se, assim, um sistema de freios e contrapesos, em que Legislativo, Executivo e Judiciário não se sobrepõem entre si. Ao primeiro cabe a realização de atos gerais, abstratos, que orientam o segundo na elaboração de atos especiais, de natureza concreta. $\mathrm{Na}$ hipótese de excesso por parte de algum deles, é função daquele último - o Judiciário - a atitude fiscalizadora, com o fim de assegurar a salvaguarda das respectivas competências (DALLARI, 2016, p. 217).

O Estado Federal apresenta-se, nesse ínterim, como uma forma de organização que confere aos Estados-membros autonomia, mas que traz em seu bojo o princípio da indissociabilidade (SILVA, 2005, p. 101). Desse modo, os entes federados não possuem soberania, ou seja, capacidade de autodeterminação, a qual é reservada unicamente ao Estado como um todo, a pessoa jurídica de Direito internacional. Àqueles é conferida somente autonomia, compreendida como a capacidade de governar-se segundo as competências dispostas constitucionalmente (SILVA, 2005, p. 100).

Diante do que foi até agora exposto, destacam-se três características basilares do Estado Federal: a) autonomia dos entes, tida como o poder de auto-organização, autoadministração e autogoverno, segundo os limites da Constituição Federal; b) participação das partes federadas na formação da vontade global, o que se dá notadamente através da estrutura paritária do Senado Federal; e c) repartição de competências, em que cada ente detém competências legislativas, político-administrativas e tributárias próprias (BARROSO, 2015, p. 207). Nesse diapasão, o Estado Federal é uma forma estatal que apresenta óbice à concentração de poder e, por consequência, à construção de governos totalitários, de modo a favorecer a democracia ao aproximar governante e governados, ao passo que estes têm mais acesso aos órgãos locais (DALLARI, 2016, p. 255).

No que tange à influência do princípio da separação dos poderes no âmbito dos poderes da União, estabeleceu-se que as funções típicas de governar, julgar e legislar cabem, respectivamente, aos poderes Executivo, Judiciário e Legislativo. Essa disposição não exclui, entretanto, a realização de funções atípicas, como o julgamento de impeachment pelo Legislativo, a elaboração de medidas provisórias pelo Executivo e a prática administrativa do Judiciário de nomear servidor público, por exemplo (FACHIN, 2015, p. 204).

Dentre os três poderes, o que usualmente tem recebido maior protagonismo, em virtude de sua atuação mais contundente (e, muitas vezes, questionável), é o Poder Judiciário, fato que justifica a sua análise mais minuciosa no tópico seguinte. 


\section{O PODER JUDICIÁRIO}

Em conformidade ao que foi exposto anteriormente, o princípio da separação dos poderes tem por escopo impedir a primazia de um poder em face de outro, de modo a ter dois elementos basilares, quais sejam: a) especialização funcional, através da qual fica estabelecido que cada órgão é dotado de uma função específica e b) independência orgânica, que garante a todos os entes o exercício independente de sua atividade, de forma não subordinada aos outros (DANTAS, 2019, p. 166).

É por tal razão que aos membros do Poder Judiciário são disponibilizadas as garantias constitucionais da vitaliciedade, da inamovibilidade e da irredutibilidade de subsídios, de forma a possibilitar aos atuantes nessa esfera de poder o livre desempenho funcional, sem que estejam sujeitos a sofrer represálias que venham a ameaçar sua imparcialidade (DANTAS, 2019, p. 166).

No que se refere às tarefas atribuídas ao poder em questão, Luiz Flávio Gomes (1997 apud FACHIN, 2015, p. 486) elenca: a) praticar o controle dos outros poderes; b) efetivar direitos fundamentais; c) realizar seu autogoverno, nas dimensões administrativa, funcional e financeira; d) aplicar de forma contenciosa a lei aos casos concretos; e e) assegurar o Estado Democrático de Direito.

Nesse aspecto, cabe ressaltar que o dever judicial de controle dos demais poderes engloba a invalidação de atos perpetrados com abuso de poder, a anulação de atos administrativos ilegais e a declaração de inconstitucionalidade de leis e atos normativos. Assinala-se, assim, a posição do Supremo Tribunal Federal como "guarda da Constituição". A prática jurisdicional também vinculase à ideia de defesa dos direitos fundamentais, em especial nas circunstâncias em que Executivo e Legislativo tenham revelado posturas insatisfatórias ao provimento do direito em enfoque. No mais, a função de manutenção do Estado Democrático de Direito refere-se à segurança da tríade "Constituição, Direito e Democracia", o que transmite, evidentemente, a necessidade de limitação de poder (FACHIN, 2015, p. 487-490).

Fazem parte da organização do Poder Judiciário o Supremo Tribunal Federal, o Conselho Nacional de Justiça, o Superior Tribunal de Justiça, o Tribunal Superior do Trabalho, os Tribunais Regionais Federais e Juízes Federais, os Tribunais e Juízes do Trabalho, os Tribunais e Juízes Eleitorais, os Tribunais e Juízes Militares e os Tribunais e Juízes dos Estados e do Distrito Federal e Territórios, nos termos do artigo 92 da Constituição Federal (BRASIL, 1988). Para fins do tema proposto no presente trabalho, dar-se-á maior relevância ao estudo do Supremo Tribunal Federal, visto que, por ser o órgão de cúpula do Judiciário, a quem foi resguardada a tarefa precípua de guardar a Constituição, é dele que advêm os exemplos mais marcantes para o exame do ativismo judicial na prática jurídica brasileira.

O Supremo Tribunal Federal é formado por onze ministros, escolhidos entre cidadãos com mais de trinta e cinco e menos de sessenta e cinco anos de idade, que contem com notável saber político e reputação ilibada, nomeados pelo Presidente da República após a prévia aprovação pela maioria absoluta do Senado Federal (DANTAS, 2019, p. 171). É tido como o "Tribunal da 
Federação", uma vez que, sendo a repartição de competências reservada à Carta Magna, o Pretório Excelso detém o papel de mantenedor do pacto federativo ao possuir o poder-dever de resguardar os ditames constitucionais ao dirimir conflitos de competências (FACHIN, 2015, p. 369, 506).

As matérias de competência do Supremo Tribunal Federal estão dispostas no artigo 102 da Lei Maior e podem ser divididas em três grupos: a) aquelas que devem ser processadas e julgadas originariamente por esta Corte, como Juízo único, conforme inciso I do artigo em questão; b) as que cabem ser julgadas através de recurso ordinário, como colocado no inciso II; e c) as julgadas por intermédio de recurso extraordinário, em única ou última instância, quando a decisão recorrida versar sobre uma das conjunturas mencionadas no inciso III (BRASIL, 1988).

Nesse diapasão, explicita José Afonso da Silva (2005, p. 560-562) que o Pretório Excelso exerce a jurisdição constitucional, que se desdobra nas vertentes da jurisdição constitucional com controle de constitucionalidade, da jurisdição constitucional da liberdade e da jurisdição constitucional sem controle de constitucionalidade. Na primeira vertente, incluem-se evidentemente as ações do controle concentrado de constitucionalidade, bem como, por via de exceção, a competência do Supremo Tribunal Federal para julgar o recurso extraordinário quando a decisão recorrida declarar a inconstitucionalidade de tratado ou lei federal, contrariar dispositivo da Constituição, julgar válida lei ou ato de governo local contestado em face da Constituição ou, ainda, julgar válida lei local contestada em face de lei federal, nos termos do artigo 103, inciso III da Constituição Federal (SILVA, 2005, p. 560).

Na modalidade de jurisdição constitucional da liberdade, encontra-se a atividade exercida em decorrência dos remédios constitucionais de proteção dos direitos fundamentais, como se dá no caso, por exemplo, da competência originária da Corte Suprema para processar e julgar o habeas corpus quando o paciente for o Presidente da República, o Vice-Presidente, os membros do Congresso Nacional, seus próprios Ministros ou o Procurador-Geral da República (art. 102, inciso I, alínea $d$ da Constituição). Já a jurisdição constitucional sem controle de constitucionalidade inclui, exemplificativamente, o processamento e o julgamento pelo Pretório Excelso dos crimes de membros de outros poderes, conforme artigo 102, inciso I, alíneas $b$ e $c$ da Carta Magna (SILVA, 2005, p. 561).

Como é nítido, o Estado Democrático de Direito adotado pelo Estado brasileiro por meio da Constituição Federal de 1988 veio a ampliar consideravelmente o papel do Poder Judiciário em comparação ao período ditatorial compreendido entre os anos de 1964 e 1985 (GOMES, 2002, p. 58). O fortalecimento do Judiciário constitui decorrência direta da construção de um Estado Constitucional de Direito, em que estão presentes o protagonismo da Constituição e a supremacia judicial para aplicá-la. O resultado alcançado é o fenômeno da judicialização, o qual pode ser traduzido no deslocamento do poder decisório de assuntos de viés político, moral ou social, que comumente seriam das esferas legislativa e executiva, para o âmbito judiciário (BARROSO, 2015, p. 437).

Trata-se de uma processo inevitável e amplamente constatado no Brasil, que: 
[...] decorre, sobretudo, de dois fatores: o modelo de constitucionalização abrangente e analítica adotado; e o sistema de controle de constitucionalidade vigente entre nós, que combina a matriz americana - em que todo juiz e tribunal pode pronunciar a invalidade de uma norma no caso concreto - e a matriz europeia, que admite ações diretas ajuizáveis perante a corte constitucional. Nesse segundo caso, a validade constitucional de leis e atos normativos é discutida em tese, perante o Supremo Tribunal Federal, fora de uma situação concreta de litígio. Essa fórmula foi maximizada no sistema brasileiro pela admissão de uma variedade de ações diretas e pela previsão constitucional de amplo direito de propositura (BARROSO, 2015, p. 440).

Referido contexto muitas vezes acaba facilitando que o Judiciário venha por praticar uma função criativa do Direito, sob o fundamento de concretizar as diretrizes constitucionais. Neste ponto, necessário frisar que, em que pese a judicialização representar uma consequência irrefreável do mecanismo institucional brasileiro, tal atividade criativa do Direito pelo Judiciário - chamada de ativismo judicial - não o é, de maneira a poder vir a representar uma subjugação aos valores do Estado Democrático de Direito, como a seguir será explanado.

\subsection{O ativismo judicial}

Até a primeira metade do século XX, em grande parte dos países ocidentais, o Legislativo encontrava-se no centro do poder do Estado, com o Judiciário limitado ao fiel cumprimento do conteúdo legal e conhecido, principalmente na França, como a "boca da lei". A partir da segunda metade do século $\mathrm{XX}$, a atividade judiciária passa a assumir uma maior visibilidade no contexto sociopolítico, em razão da força normativa atingida pelas Constituições com o término da Segunda Guerra Mundial. É nesse momento que o Poder Judiciário passa a ser vislumbrado como o protetor maior das regras e princípios constitucionais (HASSELMANN, 2019).

Assim, como já apontado em tópico anterior, originou-se um processo de judicialização, que, embora usualmente associado ao ativismo judicial, com este não se confunde. Nesse teor, ensina Luís Roberto Barroso (2015, p. 442) que a judicialização não representa uma escolha política por parte do Poder Judiciário, mas sim um resultado direto da estrutura organizacional brasileira, enquanto o ativismo judicial consiste na opção desta esfera de poder em realizar uma interpretação proativa da Constituição, ocasionando a expansão de seu alcance. Nessa toada, este último é o oposto da autocontenção, por meio da qual o Judiciário almejaria refrear a sua intervenção na seara dos outros poderes. Salutar frisar que o comportamento ativista costuma ter por elemento justificador a retração de um poder, notadamente o Legislativo.

Os posicionamentos quanto ao teor nocivo ou não do ativismo judicial são inúmeros. Para Barroso (2015, p. 443), a postura ativista do julgador poderia, em princípio, mostrar-se legítima ao buscar potencializar o texto constitucional, por intermédio, inclusive, da elaboração de regras específicas de conduta com base em enunciados vagos. Em contrapartida, Streck (2018) aduz que: 
O ativismo sempre é ruim para a democracia, porque decorre de comportamentos e visões pessoais de juízes e tribunais, como se fosse possível uma linguagem privada, construída à margem da linguagem pública. Já a judicialização pode ser ruim ou pode não ser. Depende dos níveis e da intensidade em que ela é verificada. $\mathrm{Na}$ verdade, sempre existirá algum nível de judicialização (da política) em regimes democráticos que estejam guarnecidos por uma Constituição normativa.

Essas discussões acabam por acalorar as críticas concernentes à ascensão da intervenção judicial no âmbito pátrio, relacionadas principalmente à natureza político-ideológica, à capacidade institucional e à limitação do debate. Quanto ao primeiro aspecto, defende-se que os julgadores, indivíduos não eleitos, criariam uma dificuldade contramajoritária ao exercerem, por vezes, um papel político que resulta na sobreposição das decisões proferidas por agentes públicos eleitos (BARROSO, 2015, p. 443-444).

O segundo ponto diz respeito à defesa de que a prioridade judiciária de conferir a palavra final sobre a Lei Maior não deveria ter por consequência fazer do Judiciário uma instância hegemônica. Para essa finalidade, criaram-se as teses da capacidade institucional e dos efeitos sistêmicos, através das quais argumenta-se, respectivamente, que: a) a decisão deve ser conferida ao poder que se mostre mais habilitado na matéria e b) o juiz deve ser precavido ao agir no caso concreto, visto que, muitas vezes, não tem a possibilidade de examinar os efeitos que a sua decisão causam, por exemplo, na esfera econômica. Já a crítica quanto à limitação do debate delineia que o protagonismo judiciário e a judicialização excessiva encadeariam a presença de uma elite de debate, bem como ocasionariam o deslocamento de discussões de conteúdo eminentemente político para os tribunais, o que geraria a substituição da argumentação jurídica e racional por discursos de teor político (BARROSO, 2015, p. 444-445).

Diante do quadro teórico até agora construído, é possível constatar que a posição de destaque do Poder Judiciário foi uma estipulação do próprio poder constituinte originário, que acabou por instituir a judicialização como um fator inelutável do Direito nacional. O tópico que aqui é questionado é a utilização dessa primazia pelo Judiciário para agir de forma ativista, criativa, e se esse ativismo estaria efetivamente gerando malefícios aos princípios democráticos ou, de maneira oposta, representaria uma busca pela concretização de direitos. Para avaliar tal problemática, insuficiente o estudo puramente doutrinário do assunto, motivo pelo qual passa-se, desde logo, ao exame de casos concretos notórios em que pode ser verificado o ativismo judicial exercido pelo Pretório Excelso.

\subsubsection{O ativismo judicial no cenário brasileiro contemporâneo}

O primeiro entendimento do Supremo Tribunal Federal que merece destaque é aquele em que o ativismo judicial manifestou-se através da decisão acerca da (suposta) mutação constitucional do artigo 52, inciso X da Lei Maior. Para a melhor compreensão da temática, necessário explicar que referido dispositivo determina que, na hipótese em que o Pretório Excelso vier a declarar 
a inconstitucionalidade de uma lei de maneira definitiva, poderá o Senado Federal suspender a execução, no todo ou em parte, desse diploma legal. Em verdade, trata-se de uma possibilidade de alargamento dos efeitos da decisão proferida em sede de controle difuso de constitucionalidade pela Corte, de modo que a suspensão será apta a transformar os efeitos inter partes em erga omnes (DANTAS, 2019, p. 236).

Frisa-se que a referida atuação senatorial tem caráter puramente discricionário, ou seja, será pautado pela análise da conveniência e da oportunidade da conduta. Todavia, mesmo que presente a discricionariedade desta Casa Legislativa em optar por suspender ou não a lei, o Supremo Tribunal Federal não pode escolher não comunicar o Senado Federal sobre a decisão definitiva realizada em controle difuso de constitucionalidade. Trata-se de um dever que lhe é imposto pelo seu próprio Regimento Interno, no artigo 178 (DANTAS, 2019, p. 237).

Porém, a prática jurídica tem demonstrado a adoção pelo Pretório Excelso da teoria da transcendência dos motivos determinantes, por meio da qual passa-se a entender que a ratio decidendi da decisão prolatada pela Corte em controle difuso de constitucionalidade produz efeitos gerais. Esse pensamento traz por consequências a abstrativização do controle difuso e, em linhas finais, a mudança do significado do artigo 52, inciso $\mathrm{X}$ da Constituição Federal, que passaria a disciplinar uma vinculação do Senado Federal em conferir mera publicidade à decisão proferida pelo Supremo Tribunal Federal, a qual, por si só, já teria efeitos erga omnes (DANTAS, 2019, p. 240).

Nessa hipótese, teria ocorrido uma mutação constitucional, ou seja, uma alteração informal do sentido e do alcance da norma constitucional, sem que ocorresse a modificação do seu texto. Não configuraria, dessa forma, uma reforma constitucional, uma vez que ela pressupõe um procedimento formal disciplinado na própria Lei Maior para a sua alteração (BARROSO, 2015, p. 158).

O demonstrativo mais conhecido sobre a divergência acerca da possibilidade da mutação constitucional do artigo em enfoque é o caso da Reclamação n. 4.335/AC, que foi proposta em detrimento de uma decisão do Juiz de Direito da Vara de Execuções Penais de Rio Branco/AC, que indeferiu o pedido de progressão de regime a condenados pelo cometimento de crime hediondo. A ação teve por fundamento a alegação de que o juiz haveria descumprido a decisão do Supremo Tribunal Federal no Habeas Corpus n. 82.959/SP, em que foi reconhecida de forma incidental a inconstitucionalidade do artigo $2^{\circ}, \S 1$ da Lei n. 8.072/90 e, por conseguinte, descartada a vedação à progressão de regime aos condenados por crime hediondo. Começou-se, assim, a discutir se a uma declaração de inconstitucionalidade realizada pelo Pretório Excelso em controle difuso poderia ser conferido efeito geral, mesmo sem a atuação senatorial delineada no artigo 52, inciso X da Constituição de 1988 (PANSIERI; SOUZA, 2018, p. 78-79).

Naquela oportunidade, a Reclamação foi julgada procedente, mas o contraste de fundamentos deixou às claras a controvérsia em se admitir a mutação constitucional do dispositivo (MENDES; BRANCO, 2016, p. 1176). Cita-se, por exemplo, a linha argumentativa desenvolvida à época pelo Ministro Joaquim Barbosa, para quem a mutação do artigo 52, inciso X da Lei Maior seria 
contrária à própria literalidade do seu texto, além de que a mutação constitucional somente poderia ser tida por válida em circunstâncias em que ocorresse maior lapso de tempo e falta de uso do dispositivo. Contudo, afirmou o Ministro em seu voto que, de 1988 até aquela data (19/04/2007), o Senado Federal havia suspendido a execução de cerca de cem normas declaradas inconstitucionais por aquela Corte, de modo a não configurar inércia da Casa Legislativa. Em mesmo sentido, o Ministro Ricardo Lewandowski ressaltou que a conformidade com a mutação desse dispositivo acarretaria inobservância ao princípio da separação dos poderes, cláusula pétrea (BRASIL, 2014).

Mais recentemente, foi publicado pelo Supremo Tribunal Federal (BRSIL, 2017) o Informativo n. 886, que noticiava o julgamento pela improcedência dos pedidos das Ações Diretas de Inconstitucionalidade n. 3.406/RJ e n. 3.470/RJ, ocasião em que o artigo $2^{0}$ da Lei n ${ }^{0}$ 9.055/1995 - que permitia o uso do amianto crisotila -, foi declarado incidentalmente inconstitucional, com efeitos erga omnes e vinculantes. Naquele momento, o Ministro Marco Aurélio aludiu que a atividade senatorial não poderia ser reduzida ao ponto de torná-la meramente declaratória, de forma a enfatizar que a relevância trazida pelo Código de Processo Civil de 2015 aos precedentes judiciais não poderia ser argumento para alterar um ditame da Constituição Federal, Lei que àquele se sobrepõe. Em que pese a sagacidade de tais apontamentos, verificou-se uma declaração incidental de inconstitucionalidade sem o respeito à competência privativa reservada ao Senado Federal pelo artigo 52, inciso X da Lei Maior, como foi acima elucidado.

$\mathrm{O}$ ativismo judicial contido no reconhecimento de que o artigo em questão teria sofrido mutação constitucional é nítido, ao passo que, de acordo com o que já foi explicado anteriormente, a conduta ativista ocorre quando o julgador realiza a elaboração do Direito, com frequência sob a justificativa de uma conduta omissiva do Executivo ou do Legislativo, o que ocasiona a intromissão na competência destes. Uma das facetas da ilegitimidade do ativismo nesse caso está representada na ausência da inércia por parte do Senado Federal em fazer frente à sua competência privativa, como bem demonstrou o Ministro Joaquim Barbosa durante o seu voto na Reclamação n. 4.335/ AC. Nas palavras de Flavio Quinaud Pedron e Alexandre Melo Franco de Moraes Bahia (2017), acontece que:

[...] sempre que o STF quer afirmar que está tomando uma decisão de vanguarda, ele alega que está fazendo uso da teoria da mutação constitucional - é dizer, para não afirmar que se está "legislando" sobre a Constituição, em uma atitude de poder constituinte permanente, encobre-se o ativismo sob o manto da neutralidade da mutação.

Outra conjuntura contemporânea em que o ativismo judicial ficou em evidência foi durante o julgamento da Ação Direta de Inconstitucionalidade por Omissão n. 26, de relatoria do Ministro Celso de Mello, e do Mandado de Injunção n. 4733, de relatoria do Ministro Edson Fachin. O Plenário decidiu, em 13/06/2019, que, em virtude de mora legislativa, a homofobia e a transfobia deveriam ser estipulados como tipo penal enquadrado na Lei de Racismo (Lei ${ }^{0}$ 7.716/89) até que o Congresso Nacional edite sobre a matéria. Restaram vencidos os Ministros Ricardo Lewandowski 
e Dias Toffoli, para os quais o comportamento só poderia ser punido através de lei aprovada pelo Poder Legislativo (BRASIL, 2019b).

A tese da Corte foi no sentido de que a vedação penal à prática da homotransfobia não influenciaria nem limitaria o exercício da liberdade religiosa, sob a condição de que não sejam emitidos discursos de ódio. Estabeleceu-se também que o conceito de racismo transcende elementos puramente biológicos ou fenotípicos e abarca a negação da humanidade e da dignidade de grupos vulneráveis (BRASIL, 2019b).

Muito embora o mérito da decisão seja louvável, não se pode deixar de comentar que o veredito tomado pelo Pretório Excelso acende dúvidas acerca da extensão do poder conferido à Corte. Possibilitar que um órgão do Poder Judiciário venha a instituir uma infração penal por intermédio de uma decisão judicial pautada em interpretação analógica pode vir a evidenciar não somente um contorno ao princípio da reserva legal, esculpido no artigo $5^{\circ}$, inciso XXXIX da Constituição Federal, mas também um ativismo capaz de colocar em risco a separação dos Poderes.

Repita-se que, nesse caso, o que é colocado em xeque é o aspecto formal da decisão, no que tange à competência do Supremo Tribunal Federal para "criar" um novo tipo penal; a matéria em si, ou seja, a criminalização da prática da homotransfobia, é de necessidade inquestionável e merece, certamente, ser alvo de atenção pelo legislador.

O intuito de levantar o debate a respeito da decisão judicial que determinou a configuração da homotransfobia como prática criminosa foi justamente trazer à lume que, embora o ativismo possa originar deliberações judiciais que de fato tenham muitos simpatizantes devido ao atendimento de anseios sociais, acaba-se por criar uma "brecha" no ordenamento jurídico, que torna cada vez mais difícil estabelecer um limite razoável para a atuação do Poder Judiciário.

Nessa esteira, cita-se que, em 2019, mesmo ano em que colocou a homotransfobia como tipo penal, o Pretório Excelso noticiou a abertura de um inquérito destinado a apurar fatos e infrações relativos a notícias fraudulentas (fake news) veiculadas na internet e que tenham por foco a Corte, seus ministros e familiares (BRASIL, 2019a). O presidente deste Tribunal, Ministro Dias Toffoli, designou o Ministro Alexandre de Moraes como relator, sem que fosse realizado sorteio entre os outros ministros. O inquérito foi instaurado com fundamento no artigo 43 do Regimento Interno do Supremo Tribunal Federal, o qual possibilita a abertura de inquérito pelo presidente em caso de infração à lei penal na sede ou na dependência do Tribunal. Contudo, parece ter ocorrido uma interpretação exorbitante da regra, porquanto muitos indivíduos apontam que a realização de críticas à Corte não coincide com um crime ocorrido nas dependências desta (ULIANO, [2019?]).

Os vícios do inquérito são inúmeros. O primeiro que deve ser mencionado é a determinação feita em abril de 2019 pelo Ministro Alexandre de Moraes (e, posteriormente, por ele revista) de retirar notícias publicadas por sítios eletrônicos que mencionavam o Ministro Dias Toffoli, bem como de bloquear as contas nas redes sociais de indivíduos investigados no inquérito. Na ocasião, a Ordem dos Advogados do Brasil ressaltou o perigo da ocorrência de censura e afirmou que nenhuma ofensa a órgão ou a agente público poderia ser mais maléfica do que o afastamento da liberdade de imprensa (ESTADÃO CONTEÚDO, 2019). 
Ademais, vê-se que a investigação conta com objeto indefinido, demasiadamente genérico, visto que o embasamento para que ela ocorra é a apuração de fatos que atinjam a honorabilidade e a segurança dos ministros e de seus familiares, o que evidencia a inexistência de um fato específico que sirva de objeto ao inquérito. A necessidade de um objeto determinado a ser investigado é percebida no artigo $5^{\circ}, \S 1^{\circ}$ do Código de Processo Penal, que traz a disposição de que o inquérito deve conter, sempre que possível, a narração do fato, com todas as suas circunstâncias (ULIANO, [2019?]).

Além disso, a designação direta do Ministro Alexandre de Moraes como relator do inquérito viola o ditame da livre distribuição e, consequentemente, da imparcialidade, conjuntura que atinge o artigo 66 do próprio Regimento Interno do Supremo Tribunal Federal. Também está presente a violação ao sistema acusatório adotado pela Lei Maior, ao passo que o Poder Judiciário não pode ter, ao mesmo tempo, a função de acusar (que traz por pressuposto o poder de investigar) e a função de julgar (ULIANO, [2019?]).

A esse respeito, a Associação Nacional dos Procuradores da República (2019) divulgou nota em que sumariza:

Desde sua gênese, a investigação citada afronta princípios elementares e muito caros ao Estado Democrático de Direito. Há inequívoca usurpação de atribuição do Ministério Público ao violar o sistema acusatório, conquista civilizatória que exige a separação das funções de defender, acusar e julgar; confronta a própria competência da mais alta Corte, vez que não há investigado, até agora, sujeito à prerrogativa de foro no STF; ignora o princípio do juiz natural, vez que não houve sorteio para a escolha do ministro relator e, por fim, o objeto da investigação é múltiplo, indeterminado e incrementado a cada medida cautelar expedida de ofício.

Tendo em vista os fatos até então relatados, percebe-se que o ativismo judicial, notoriamente o desenvolvido pelo órgão de cúpula do Judiciário, tem representado uma constância na usurpação de competências, a inviabilizar tanto a independência e a harmonia entre os Poderes quanto o dever de resguardo da Constituição conferido ao Supremo Tribunal Federal.

Como bem coloca Streck (2013), os dados e apontamentos jurídicos

[...] apontam para o perigo que o ativismo judicial representa para a representação política, até porque uma ofensa à Constituição por parte do Poder Judiciário sempre é mais grave do que qualquer outra desferida por qualquer dos outros Poderes, porque é ao Judiciário que cabe sua guarda. Quem nos salvará se não há mais salvadores? Ou pior: quem nos salvará dos salvadores?

O descumprimento ora evidenciado ao princípio da separação de poderes constitui, dessa maneira, não somente uma afronta à cláusula pétrea instituída pelo artigo $60, \S 4^{0}$, inciso III da Carta Magna, mas também uma desídia à conquista do Estado Democrático de Direito, que, ao fundar-se no constitucionalismo, prega a limitação do poder como um de seus elementos basilares 
(BARROSO, 2015, p. 112). O que se permite e determina ao juiz é que, ao realizar a necessária tarefa de interpretar o texto da Lei Maior, assim o faça com fundamento nos princípios da hermenêutica constitucional, haja vista que aplicar o Direito em um Estado Democrático de Direito representa, antes de tudo, aplicar a Constituição (GOMES, 2002, p. 59).

\section{CONCLUSÃO}

Ante o exposto, conclui-se que não é possível constatar a viabilidade ou não do ativismo judicial tão somente com fulcro em análises doutrinárias, já que são numerosas e usualmente divergentes. Carece-se, assim, do exame concreto da atuação judiciária brasileira, em especial no que se refere ao seu órgão máximo. Nessa linha, acabou por ser demonstrado que o Supremo Tribunal Federal, de forma frequente, busca acobertar um comportamento ativista com justificativa em uma pressuposta mutação constitucional, conforme trazido no debate acerca do artigo 52, inciso X da Constituição de 1988.

No entanto, tem-se que a mutação constitucional tem como uma de suas diretivas o atendimento aos sentidos possíveis do dispositivo sub examine, razão pela qual, diante da literalidade do artigo acima mencionado, a mutação não pode ser configurada, mas sim um ativismo por parte da Corte, que, através de uma atitude criativa, usurpou uma competência privativa do Senado Federal, que não tinha restado inerte diante de suas prerrogativas constitucionais.

Já a criminalização da homotransfobia chamou a atenção pelo fato de que, por trazer em seu âmago uma intenção nobre, acabou por passar despercebida no que diz respeito à constitucionalidade de o Pretório Excelso vir a tomar o lugar do Legislativo para, através de uma decisão judicial, definir um tipo penal que, necessariamente, deveria ser estipulado por lei. A demasiada liberalidade que tem sido conferida ao Tribunal em comento resulta em hipóteses de manifesto abuso de poder e ativismo, como visto no caso do inquérito instaurado de ofício pela Corte para proteger a honra de seus ministros, o apelidado "inquérito das fake news".

Procurou-se mostrar, sobretudo, que apesar de algumas condutas ativistas trazerem por consequência uma efetiva concretização dos direitos fundamentais (a exemplo da hipótese da tipificação da homotransfobia), elas acabam por abrir margem para que os julgadores atuem com uma discricionariedade que, muitas vezes, resulta na hegemonia do Judiciário e, por via lógica, no ferimento ao princípio da separação dos poderes. Afinal de contas, se é possibilitado ao Judiciário agir com ativismo em circunstâncias em que haja a necessidade social, a quem caberia impor-lhe limites quando essa postura proativa não se faz necessária nem benéfica ao Direito pátrio? A quem caberia decidir se o ativismo judicial seria "bom" ou "mau" no contexto analisado?

Isto posto, retoma-se ao problema que o presente artigo buscou trazer à luz do debate: o ativismo judicial, sobretudo o desenvolvido pelo órgão de cúpula do Judiciário, é vislumbrado como ferramenta de concretização de direitos ou, de modo contrário, está usualmente atrelado à violação dos princípios democráticos?

Diante de todas as considerações tecidas por este estudo, coaduna-se com a ideia da 
predominante lesividade da conduta ativista, de modo a se concluir que o ativismo judicial traz como prejuízos alargar de modo extenso as determinações legais e constitucionais e reduzir a possibilidade de controle de atos viciados, ao passo que costuma valer-se da tese de efetivação dos valores constitucionais para, contrariamente, gerar a usurpação de competências e a subjugação de ideais democráticos, tal como a separação dos poderes.

\section{REFERÊNCIAS}

ASSOCIAÇÃO NACIONAL DOS PROCURADORES DA REPÚBLICA - ANP. Nota pública: hora de retomar o caminho da legalidade. Brasília: ANP, out. 2019. Disponível em: https://www. anpr.org.br/imprensa/noticias/23624-nota-publica-hora-de-retomar-o-caminho-da-legalidade. Acesso em: 9 abr. 2020.

BARROSO, Luís Roberto. Curso de direito constitucional contemporâneo. 5. ed. São Paulo: Saraiva, 2015.

BRASIL. Constituição (1988). Constituição da República Federativa do Brasil. Brasília: Presidência da República, 1988. Disponível em: http://www.planalto.gov.br/ccivil_03/ constituicao/constituicao.htm. Acesso em: 09 abr. 2020.

BRASIL. Supremo Tribunal Federal. Informativo n. 886. Brasília: STF, 2017. Disponível em: http://www.stf.jus.br/arquivo/informativo/documento/informativo886.htm. Acesso em: 9 abr. 2020.

BRASIL. Supremo Tribunal Federal. Presidente do STF abre inquérito para apurar ameaças e fake news que têm a Corte como alvo. Brasília: STF, mar. 2019a. Disponível em: http://www. stf.jus.br/portal/cms/verNoticiaDetalhe.asp?idConteudo=405790\&caixaBusca=N. Acesso em: 9 abr. 2020.

BRASIL. Supremo Tribunal Federal. Reclamação n. 4.335/AC. Reclamante: Defensoria Pública da União. Reclamado: Juiz de Direito da Vara de Execuções Penais da Comarca de Rio Branco. Relator: Min. Gilmar Mendes. Brasília, 20 de março de 2014. Disponível em: http://redir.stf.jus. br/paginadorpub/paginador.jsp?docTP=AC\&docID=630101. Acesso em: 9 abr. 2020 .

BRASIL. Supremo Tribunal Federal. STF enquadra homofobia e transfobia como crimes de racismo ao reconhecer omissão legislativa. Brasília: STF, jun. 2019b. Disponível em: http:// portal.stf.jus.br/noticias/verNoticiaDetalhe.asp?idConteudo=414010. Acesso em: 9 abr. 2020.

DALLARI, Dalmo de Abreu. Elementos de teoria geral do Estado. 33. ed. São Paulo: Saraiva, 2016.

DANTAS, Paulo Roberto de Figueiredo. Direito processual constitucional. 9. ed. São Paulo: Saraiva Educação, 2019.

ESTADÃO CONTEÚDO. "Liberdade de imprensa é inegociável”, diz OAB ao STF. Revista Exame, São Paulo, 16 abr. 2019. Disponível em: https://exame.abril.com.br/brasil/liberdade-deimprensa-e-inegociavel-diz-oab-ao-stf/. Acesso em: 9 abr. 2020. 
FACHIN, Zulmar. Curso de direito constitucional. 7. ed. Rio de Janeiro: Forense, 2015.

GOMES, Sergio Alves. Hermenêutica jurídica e constituição no estado de direito democrático. Rio de Janeiro: Forense, 2002.

HASSELMANN, Gustavo. Ativismo judicial no STF: acertos ou desacertos? Migalhas, [s.l.], 25 jan. 2019. Disponível em: https://www.migalhas.com.br/depeso/294916/ativismo-judicial-no-stfacertos-ou-desacertos. Acesso em: 9 abr. 2020.

MENDES, Gilmar Ferreira; BRANCO, Paulo Gustavo Gonet. Curso de direito constitucional. 11 ed. São Paulo: Saraiva, 2016.

PANSIERI, Flávio; SOUZA, Henrique Soares. Mutação constitucional à luz da teoria constitucional contemporânea. Porto Alegre: Livraria do Advogado, 2018.

PEDRON, Flavio Quinaud; BAHIA, Alexandre Melo Franco de Moraes. Crença da mutação constitucional, aplicada pelo STF, é equivocada. Revista Consultor Jurídico, São Paulo, 16 dez. 2017. Disponível em: https://www.conjur.com.br/2017-dez-16/diario-classe-crenca-mutacaoconstitucional-aplicada-stf-equivocada. Acesso em: 9 abr. 2020.

SILVA, José Afonso da. Curso de direito constitucional positivo. 26. ed. São Paulo: Malheiros, 2005.

STRECK, Lenio Luiz. O ativismo judicial existe ou é imaginação de alguns? Revista Consultor Jurídico, São Paulo, 13 jun. 2013. Disponível em: https://www.conjur.com.br/2013-jun-13/ senso-incomum-ativismo-existe-ou-imaginacao-alguns. Acesso em: 9 abr. 2020.

STRECK, Lenio Luiz. O futuro do STF: na retranca, como diz Toffoli, ou no ataque? Revista Consultor Jurídico, São Paulo, 6 dez. 2018. Disponível em: https://www.conjur.com.br/2018dez-06/senso-incomum-futuro-stf-retranca-toffoli-ou-ataque. Acesso em: 9 abr. 2020.

ULIANO, André Borges. Entenda por que o inquérito instaurado por Dias Toffoli é ilegal. Gazeta do Povo, [2019?]. Disponível em: https://www.gazetadopovo.com.br/instituto-politeia/ inquerito-toffoli-ilegal/. Acesso em: 9 abr. 2020.

Como citar: BUZALAF, Mirelle Neme; TACLA, Silvia Regina; SACOMAN, Sofia Sanches. Ativismo judicial: uma análise do papel do Poder Judiciário no cenário brasileiro contemporâneo. Revista do Direito Público, Londrina, v. 16, n. 2, p. 10-25, ago. 2021. DOI: 10.5433/24157-108104-1.2021v16n2p. 10. ISSN: 1980-511X

Recebido em: 17/04/2020

Aprovado em: 19/01/2021 